\title{
ЕСТЕТИЧНІ РОЗВІДКИ \\ ПОСТСТРУКТУРАЛІЗМУ: \\ Ю. КРІСТєВА, Ж. ДЕРРІДА
}

\begin{abstract}
Д.М. Скальська
Для мистецької культури ХХ ст. постмодерн асоціюється 3 «трансавангардом», «постструктуралізмом», «неоструктуралізмом», «суперструктуралізмом», дає підстави замислитись над тим, що пов'язує пафос високого мистецтва з гіпертекстом, гіперсередовищем, гіперпростором, маргінальністю, перфомансом. Постмодерністські пошуки фактологічно і проблемно не лише розширили предметне поле філософствування, а й фундаментально зрушили такий незамінний спосіб освоєння світу, яким є художня творчість; створили передумови для вирішення питань не лише людської свободи, а й відповідальності перед нею.

У середовищі французьких семіотиків минулого сторіччя, які об'єднались навколо часопису «Тель-Кель», а також у період політичного та інтелектуального протесту, відомого під назвою «Травень 1968 р.» з'являються нові імена психоаналітиків та науковців. Серед них визначне місце належить Юлії Крістєвій, в працях якої поляризується термінологія кількох різновидів структуралізму, а широкий діапазон творчості охоплює не лише проблематику семіотичного аналізу та літературних структур, а й питання жіночої особистості, гендеру, фемінізму. Окрема увага приділяється вже традиційній для постмодернізму темі-стосункам між суб'єктом та Іншим, де автор виголошує дуалістичну сутність структури суб'єктивізації.

Естетичні ідеї Ю.Крістєвої найвиразніше проявляються в її міркуваннях над долею митця, який виконує певну символічну роль в
\end{abstract}

Актуальні проблеми духовності

(Відп. ред.: Я.В. Шрамко)

Кривий Ріг (2007), 289-298 
постмодерністській культурі. Він виявляє здатність «означувати неозначуване» і відтворювати «суб'єкта в процесі» засобом залучення аналітики лінгвістичних структур до процедур суб'єктивації. Про це йдеться в таких працях Крістєвої як: «Бахтін, слово, діалог і роман» (1967), «До семіології параграм» (1969), «Руйнація поетики» (1970) та інших. Коментуючи теоретичні розробки Михайла Бахтіна стосовно визначення «жанрів мови» та «статусу слова», Крістєва ставить за мету відшукати специфіку логіки сучасної семіології. 3 позицій аналітика-структураліста вона розкриває етапи смислотворення поетики, спираючись на дослідження Бахтіна, якими той займався протягом майже 40 років. Бахтін завжди виступав активним поборником формалізму, і саму манеру його письма Крістєва вважає «пророчою». Впливовість позицій Бахтіна полягає в його основній концепції про «літературне слово». Воно виступає тим центром, тією площиною, в якій відбуваються діалоги різновидів авторського письма, порушується питання діахронії та синхронії історії тексту.

Культурний контекст, на думку Крістєвої, Бахтіну ідеально вдається інтерпретувати залучивши до термінологічного обігу поняття карнавалу. Вона пише: «Карнавальний дискурс зламує закони мови, що оберігаються граматикою та семантикою, виступаючи тим самим втіленням соціально-політичного протесту проти офіційного лінгвістичного коду, з одного боку, та протестом проти офіційного закону - 3 іншого» [13, с.428]. Крістєва також зважає на інші бахтінські концепти, такі як «діалог», «поліфонія», «меніппея» та радикально переосмислює їх. Так, якщо «карнавальна стихія» літературного тексту має подвійну природу, то вона ніяк не зводиться, на думку Крістєвої, до пародії, хоча наявність співіснування трагічного та комічного можна констатувати. Саме тому карнавальний сміх парадоксально сприймається як щось «серйозне», він в певний момент «завмирає» і може трансформуватись в «смертоносний», «цинічний» і т. п.

Аналогічна ситуація виникає з бахтінським «діалогізмом», який виявляє в письмі на лише суб'єктивне, а й комунікативне, а точніше, інтертекстове, що вказує на «амбівалентність письма». Крістєва пише про сократичний діалог, який, на її думку, проіснував недовго і поступився іншому діалогічному жанру, такому як меніппея. Свою назву меніппея отримала від імені філософа III в. до н.е. Меніппа, а сам термін означає один з жанрів карнавального фольклору. На прикладі меніппеї як «тексту соціальної діяльності» Крістєва демонструє, чому класицизм чи будь-яке інше авторитарне суспільство не може себе виразити в монологічній формі роману (епос). Вона вводить типоло- 
гізацію текстів-дискурсів і серед них виділяє, зокрема, «поліфонічний роман», роман-бунт: «Немає нічого дивного в тім, що роман сприймається або як нижчий жанр (так відносився до нього класицизм і співзвучні класицизму політичні режими), або як жанр бунтарський (я маю на увазі великих авторів поліфонічних романів, в який би час вони не жили, - Рабле, Свіфта, Сада, Лотреамона, Кафку, Батая: я називаю лише тих, хто перебував і перебуває за порогом офіційної культури). На прикладі романного слова і романної розповідної структури ХХ ст. можна було б показати, яким саме чином європейська думка долає власні конститутивні ознаки, такі, як „тотожність“, „субстанція“, „каузальність“, „дефініція“, і засвоює цілком інші, як-то: „аналогія“, „відношення“, „опозиція“, іншими словами, засвоює принцип діалогізму та меніппейної амбівалентності» [13, с.450-451].

Для проведення структуралістської аналітики над Текстом Крістєва вводить таке поняття як «семаналіз». Він дозволяє теоретику відійти від проблем інтерсуб'єктивності і працювати в площині інтертекстуальності, тим самим розглянувши можливості «прочитання» поетичної мови. Про те, що поетика не здатна підібрати ключа до інтертексту і лише описує його інваріантну структуру, Крістєва продовжує полеміку в своїх дослідженнях «Руйнація поетики» та «До семіології параграм». В них автор знову піднімає принципове для постструктуралізму питання опозиції твір/текст, доводить багатомірність концепту «інтертекст», його глибинне діахронічне значення. Аналізуючи російську формальну школу та літературно-критичний доробок таких іiї персоналій як М.Бахтін, Ю. Тиянов, П. Медведєв, В.Волошинов, А. Веселовський Крістєва, на противагу однозначному «структурному тлумаченню», пропонує принцип множинного (поліфонічного) смислового «прочитання».

Піддаючи критиці російський формалізм, що склався, за спостереженням Крістєвої, на базі структурної лінгвістики, яка прийшла на зміну порівняльно-історичному мовознавству та поетичній практиці футуристів, автор прогнозує: «В кінцевому результаті, це означає, що текст підводиться під ту, чи іншу лінгвістичну теорію (як правило, під категорії мови, і ніколи - під категорію дискурсу) і в крайньому випадку може бути співставлений з кожною із них, але так, що специфіка літературного об'єкту - в рамках історії різними способами означувана - виявляється втраченою, а „поетичний“ дискурс залишається непохитним і виявляється набором категорій та способів самоперевірки, а зовсім не носієм об'єктивного знання» [14, с. 459].

Стосовно структуралістського втілення авторської присутності в 
«мові», то Крістєва як естетик постструктуралізму вбачає таку можливість у множині дискурсних інстанцій, репрезентованих в інтертекстових кодах. В поетиці, на відміну від структуралізму, який відстоював ї̈ як одну з наук (про мистецький твір), Крістєва виявляє «дисципліну з невизначеним предметом», а літературу висуває одним із способів «семіотичного виробництва».

Ідеям синтезу найрізноманітніших текстів - філософських, літературних, лінгвістичних, соціологічних, психологічних та підпорядкування їх постмодерністському вченню про деконструктивізм присвячено творчу діяльність Жака Дерріда. Виходячи з того, що постструктуралізм не утворює організаційної єдності і не має спільної програми, його представники працювали з естетичним матеріалом як чимось середнім між теорією та вимислом, філософією і літературою, лінгвістикою і риторикою. Не оминула така учать і Жака Дерріда, який намагається уникнути мислення протилежностями (на зразок ідеальний (реальний), а пропонує застосувати особливі властивості мови, названі ним «розрізнюванням». Багато запозичивши від Гегеля, Ніцше, Гуссерля, Хайдеггера, Фрейда, мислитель прилучився до сприйняття літературного авангарду (Арто, Батай, Бланшо, Клоссовський). На основі таких впливових «слідів» Дерріда здійснює «деконструкцію» (на відміну від деструкції) метафізичної традиції та авторський риторичний дискурс в естетику. У відповідності до ситуації, яка була притаманна Постмодерну, головними об'єктами критичного розгляду виступили тексти західно-європейської метафізики, в яких Дерріда вбачає можливість здійснювати деконструкцію «онто-тео-телео-фалло-фонологоцентризму» європейської антропології.

Деконструкція пов'язується Деррідою з першовитоками, істинним розумінням буття, легітимацією філософії як епістеми, однак не на засадах деструкції, а на нових позитивних смислотвореннях. Продукування смислів відбувається через вияснення в текстах вихідних понять, нашарувань метафор, які приводять до несамототожності тексту й інваріантності його інтерпретацій, а тому конструктивна роль відводиться письму.

Фактично, з персоною Дерріди можна пов'язати ту еволюцію, яка відбулась в постмодерні: від структуралізму до постструктуралізму. В своїх естетичних концептах Дерріда виступив з критикою окремих позицій структуралізму, зокрема стосовно «логоцентризму» та його настанов. На основі розвитку ідей Барта, вчений здійснює заміну науки про мову - граматики на особливу науку про письмо - грамматологію («Голос і феномен», «Про грамматологію», «Письмо й відмін- 
ність»- усі опубліковані 1967р.). За межі класичного логосу виходять такі елементи «письма» в текстах як повтор, копія, слід, «грамма», тобто виникає необхідність долучення, заміщення, доповнення самодостатності в художніх текстах Ніцше, Фрейда, Арто, Батая, Фуко, де Соссюра чи Левінаса. Метафізичне мислення, на думку філософа, слід замінити діалектичним процесом, який би інсценіював «переживання відсутнього в теперішньому часі». Для такого акту $є$ необхідним суспільний досвід, через який текст пройде «випробування». Такими антропологічними інтенціями наповнює і обгрунтовує автор емпіричний досвід у прочитанні художніх творів та формуванні естетичних категорій, які б відповідали практиці літературного та мистецького авангардизму.

В дусі заперечення класичного «логоцентризму» (первинність логосу - як закону та слова водночас), автор виступає також проти філософського поділу на суб'єкт та об'єкт чи інших «метафізичних» суперечностей, чим наближається до відомих міркувань Хайдеггера. Для нього принциповою $є$ поправка щодо розмежування структурною лінгвістикою «озвученого» слова (мови) та фонетичного «письма». 3 цього моменту власне й розпочинається деррідаїстська концепція науки про «письмо» - грамматологія. Аналогічно тому, як Барт виокремлює «саморефлектуюче письмо», у Дерріди «письмо» виступає незалежним від автора та читача і створює відкритий контекст, власне текстуальне поле. Користуючись своїм методом «деконструкції Дерріда здійснює розчленування тексту (об’єктів гуманітарної культури). Текст наділяється гетерогенністю, насичений культурно-мовними кодами, які зберігають соціальну пам'ять людства, несуть ознаки таких проявів, як діалог, конфліктність, агресія, асиміляція та ін. Текст, таким чином, складає культурно-антропологічну полісемію, а Дерріда виводить формулу: «Позатекстової реальності взагалі не існує» [5, c. 313].

В людині та культурі Дерріда відшукує «інакше всезагальне», яке знаходиться на «інших рівнях» колективного та індивідуального, аніж раціональне мислення в його традиційному сенсі. Він працює з поняттями «інакшість», «відмінність», «розрізнення» (différance), «блукання без мети» (destinerrance). Це те, що не може бути представлене у формі образу, репрезентації, показу наявного та того, що все ж присутнє, це також і не рівність та двоосновність одного та іншого, тобто «такого» та «іншого». Їхня «відмінність»- це те, що вказує на різницю між тим, що саме так і не інакше «розуміється» і тим, що саме так і не інакше «описується» [12, с. 651]. Дерріда проявляє етичну стурбованість 
щодо ставлення до Іншого та щодо привласнення якоїсь частки від тієї іншості. В своїх працях він вводить множинність кодів та застосування певних гібридних слів, таких як: археписьмо, археслід, фармаком, гімен, додаток, парергон тощо, створюючи «квазі»-трансцендентну ситуацію для критиків та дослідників власних творів.

Філософсько-естетичні неологізми, які вводить Дерріда, призначаються ним для того, щоб висловити невизначеність значень постмодерністської доби, а водночас і відкинути традиційний логоцентризм щодо надання переваг мовленню над письмом. Аналогічно, на зміну поняттям «буття», «субстанція», «акцеденція», «суб'єкт», «екзистенція», «свідомість» пропонуються умоглядні структури: «логосміф», «інтелігібельність-сенсибільність», «логіка-риторика», «моваписьмо», «інтуїція-сигніфікація», тобто від застарілої форми мислення та світовідчуття як «присутності» слід вдатися до нової парадигмисхемоцентричного мислення [12, с. 651]. Фактично, Дерріда, подібно до Арістотеля, здійснює переворот, i, якщо в античного філософа,- це був примат логіки над риторикою, то мислитель-постмодерніст надає парадоксальної переваги риториці та естетиці над логікою.

Так само як Ю.Крістєва, Ж.Дерріда співпрацював з групою «Тель-Кель», що випускала часопис, який був проголошений журналом авангардизму і призначався в основному для дослідження статусу письма, культури й політики. В ньому зосередили свої перспективи кілька різних галузей: літературна критика, лінгвістика, етнографія, психоаналіз. Вплив Дерріда був вагомим, особливо це стосується написання ним ряду гостро критичних есе, які поєднали естетичне розуміння «науки про письмо» 3 психоаналітичною теорією. В есе «Фрейд та сцена письма», яке було опубліковане журналом в 1966 р., Дерріда запропонував нове прочитання Фрейда у зв'язку з поняттям «письмо» (L'Ecriture). Виходячи з того, що сучасна філософія, а по суті, йдеться про метафізику свідомості, суб'єктивності й гуманізму наділена такою вадою як догматизм, Дерріда здійснює деконструкцію на основі звернення до несвідомого.

На відміну від класичного психоаналізу, несвідоме у Дерріда позбавлене певно визначеного місця, воно водночас перебуває скрізь і ніде, йому притаманні проблеми темпоралізації пов'язані з «позачасовістю» позасвідомого. На думку Дерріда, позасвідоме постійно втручається в діяльність свідомого, викликаючи в ній своєю грою сум'яття та безладдя, тому воно торкається ряду антропологічних проблем: «Перш ніж визначити буття як присутність, слід помислити життя як слід. Це єдина умова, яка дозволяє сказати, що життя це смерть, що повто- 
рення та перебування по той бік принципу задоволення $є$ вихідним i спорідненим всьому, що вони трансгрессують» [10, с. 342]. Дерріда був переконаний, що культурологічний довідник чи словник естетичних термінів може бути ускладнений для окремої епохи або історичного циклу, але не може бути універсальним для розуміння явищ мистецтва всіх часів. Поєднавши структуралістський метод з герменевтикою та психоаналізом, Дерріда в такий спосіб приходить до методу «творчої гри», який самодостатньо оцінює художню якість не лише як властивість твору мистецтва, а й принцип людського мислення в цілому. I, що характерно, при цьому, ніяк не зводиться до суто логічних операцій. Такі висновки дали підставу назвати естетика постструктуралізму Дерріда «апостолом свобідної гри». Стосовно критеріїв антропологічного наукового знання, то вони, на думку філософа, покликані виявляти той незаперечний факт, що всі явища світу включають в себе «фермент естетичного». Таким чином, Деррідою формується новий тип теоретичної рефлексії - художньо-літературне мислення.

В своєму есе «Театр жорстокості та завершення вистави» (1967), теоретик мистецтва продовжує досліджувати тему антропологізації всіх форм прояву художнього та його еволюційних процесів в умовах Постмодерну. Постать Антонена Арто, що стала об'єктом уваги багатьох психоаналітиків, зосередила в собі найбільш точний штрих постмодерністських інтенцій. Новеліст та драматург Арто відомий був своїми автобіографічними творами та власне тим, що пізніше стали називати «театром жорстокості». В центрі його авангардистсько-сюрреалістичних комбінацій були відверті сцени, де людське тіло доводилося до його фізичних та емоційних меж. Сам Арто пережив особисту трагедію, був душевнохворим, вірогідною причиною його смерті стало самогубство. Відвідавши в 1947 році виставку картин Ван Гога, написав есе, в якому, порівнявши своє божевілля з Ван Гоговим, висловив думку про те, що душевна хвороба-це щось шляхетне. Насправді, божевілля і сформувало, і спотворило творчість цього деррідівського персонажа. Через театралізований образ-символ Дерріда спробував донести до читача свою постмодерністську ідею дезінтеграції та деконструкції. «Театр жорстокості» пропагує філософію приреченості, відчаю, людської самотності, а з погляду постструктуралістської естетики, як стверджує Дерріда: «Театр жорстокості-це не лише видовище без глядача, а ще й слово без слухача» [9, с. 405]. В ньому лише естетик здатний побачити і зрозуміти яким чином художник водночас i творить, і споглядає, подібно до того як необхідність та гра, боротьба та гармонія поєднуються в пари для того, щоб створити художній 
твір.

Дерріді також належить унікальна заслуга у створенні не лише художньо-літературного, а й філософсько-літературного мислення. Слідом за Бартом, йому вдається нівелювати відмінність між літературою, літературною критикою та літературознавством. Екскурс до філософських текстів він здійснює за допомогою критики такого літературного типу, за якого риторика стає основним засобом аналізу, вона уникає відповідності науковим критеріям і підводить текстуальний ансамбль до рівня творчої діяльності, творчої гри.

Про те, що художня мова завжди перебуває в стані гри, йдеться у розвідці «Структура, знак і гра в дискурсі наук про людину», поворотному есе, що його Дерріда прочитав як лекцію в університеті Джонса Гопкінса в 1966 р. Літературна теорія, з погляду автора, перебуває у двох іпостасях. По-перше, за повної відсутності ідеї тотальності, структура розуміється як поняття без «телоса» або суб'єкта-детермінанта, і тоді література виконує функцію штучної, глибоко рефлективної форми репрезентації. Мова за тих умов тлумачиться як історично та ідеологічно вмотивована. По-друге, теоретики та критики органічно сприйняли цей деструктивний або риторичний підхід до мови, переносячи її на околиці культури, що знаходиться в стані гнітючості та відчуження. В своєму есе Дерріда проголосив ці два імпульси панівними «інтерпретаціями інтерптерацій», також фундаментальною проблематикою, яка утворює горизонт епістеми постмодернізму [8, c. 457477].

Мистецтво в концепції Дерріда розглядається постійно як знак, як спосіб «графії» - просторово-часовий запис у формі «археписьма», перманентно структуруючого та цілком довільно «записаного» механізму ([3], [6], [11]). Піддаючи постійній критиці лого-, фоно-центризм, Дерріда пропонує «новий структуралізм», який би досліджував межі власних можливостей та чинників. Така позиція Дерріда була зустрінута неоднозначно у філософському та науковому світі. Багато авторів виступили в скептично налаштованій опозиції, визначаючи методи Дерріда антиестетичними, серед них, зокрема, такі як С. Уінсмор, В.Бержин, Дж. Блокер. Окремої ваги теорії деконструкції надають феноменологи. Так, Б. Вальденфельс розглядаючи теоретичні межі феноменології, називає постструктуралістський концепт Дерріда «деконструкцією» 3 двосторонньо загостреним лезом», маргінальною феноменологією і навіть маргінальною герменевтикою [1, с. 125]. В грунтовному дослідженні Т. Гуменюк «Жак Дерріда і постмодерністьке мислення» (1999) автор «деконструктивістського «письма» наділяє- 
ться рисами потенційного апокаліптика: «Апокаліпсис відкриває істину, а саме - постструктуралізм, і ця істина надсилає повідомлення власному пророкові-провіснику, тобто Дерріда, щоб він провістив її, викриваючи тих, хто проти неї, тобто тих, хто вірить у „видиму“ язичницьку істину, i, таким чином, не бажає визнавати істину за межами розрізнювання і неправди або добра і зла, яка єдина для правих та винних і на всіх однаково світить, хоча сама невидима й нечутна» [2, c. 227].

За цілковитим переконанням того, що «ніщо не існує поза текстом», а свідомість митця заповнена «сумою текстів», Дерріда поєднує філософію з літературознавством в неопостструктуралістській критиці, базуючись на метафоричності мови, спорідненості філософії та поезії ([4], [7]). У своїх завершальних естетичних висновках мислитель доводить, що знання, істина та реальність виникають не з досвіду, а $з$ мови як нестабільно структурованої системи. В такий спосіб відбувається релятивізація та демістифікація метанаративів та транскультурних феноменів сучасної західної філософсько-антропологічної думки.

Естетичні розвідки постструктуралізму підготовлені двома процесами - декадентством та авангардом, запрограмували іншу шкалу цінностей та естетичних терміналів. 3 одного боку, - відбувається переважання локального над тотальним, з іншого, - продовжується пошук універсальних засобів комунікації. Мистецтво виходить в «хаососферу», «простір непередбачуваного», опановуючи його мовою метафор, алегорії, символів, іронії, переорієнтовуючись від «художнього твору» на «художню конструкцію». Цей процес супроводжується стильовим «анархізмом», відзначається рисами еклектизму, коллажності, цитування та монтажу, застосуванням прийомів гри. В модерному та постмодерному контексті відкриваються значні перспективи для дослідження таких естетичних феноменів як карнавальність, стилізація, соціальний театр. Таким чином, мистецтво, виступаючи пластом концентрації художніх досягнень людства, виявляється найдосконалішим втіленням у специфічній формі його самосвідомості та життєвої сили. Через «естетичне» здійснюється антропологічний вимір феномену людини, фіксується ідея людської цілісності, наповнюються новим сенсом та розширюються межі теорії чуттєвості.

\section{1 Бібліографія}

[1] Вальденфельс Б. Вступ до феноменології. - К.: Альтерпрес, 2002. 
[2] Гуменюк T.К. Жак Деррида и постмодернистское мышление.К.: Нора-Принт, 1999.

[3] Деррида Ж. Голос и феномен и другие работы по теории знака Гуссерля.-СПб.: Алетейя, 1999.

[4] Деррида Ж. Два слова для Джойса. Ad Marginem'93. - M.: Ad Marginem, 1994. - C. 354-383.

[5] Деррида Ж. О грамматологии. (Пер. Н. Автономовой). - М.: Ad Marginem, 2000.

[6] Деррида Ж. Письмо и различие.-М.: Академический Проект, 2000.

[7] Деррида Ж. Письмо к японскому другу // Вопросы философии. 1992. - № 4. - C. 53-57.

[8] Дерріда ЖК. Структура, знак, гра в дискурсі гуманітарних наук // Слово. Знак. Дискурс. Антологія світової літературно-критичної думки. - Львів: Літопис, 1996. - С. 457-477

[9] Деррида Ж. Театр жестокости и завершение представления // Французская семиотика: От структурализма к постструктурализму. - М.: Прогресс, 2000.- С. 379-406.

[10] Деррида Ж. Фрейд и сцена письма // Французкая семиотика: От структурализма к постструктурализму.- М.: Прогресс, 2000.C. 336-378.

[11] Деррида Ж. Эссе об имени.-М.: Алетейя, 1998.

[12] Iсторія філософії / За ред. В.І. Ярошовця. - К.: Парапан, 2002.

[13] Кристева Ю. Бахтин, слово, диалог и роман // Французская семиотика: От структурализма к постструктурализму. - М.: Прогресс, 2000. - С. 427-457.

[14] Кристева Ю. Разрушение поэтики // Французская семиотика: От структурализма к постструктурализму. - М.: Прогресс, 2000.C. 458-483. 